\title{
Scientific Achievement Award: Richard D. Weisel, MD
}

\author{
Alec Patterson, MD
}

The American Association for Thoracic Surgery (AATS) established its Scientific Achievement Award to recognize individuals who have made extraordinary scientific contributions in the field of thoracic surgery. This award is the highest recognition that the Association can bestow on a member. Previous recipients are Drs John Kirklin, Norman Shumway, Michael DeBakey, Denton Cooley, Alain Carpentier, Gerald Buckberg, and Andrew Weschler. Dr Richard Weisel, through his visionary work and commitment to scientific education, is richly deserving of this award.

Richard Weisel attended Yale University and Marquette Medical School. He completed surgical training at Boston University. During his general surgical training, he spent 2 years as a research fellow in thoracic surgery. The combination of basic experimental and clinical investigations in the intensive care unit resulted in a new measure of heart function - the increase in stroke work index induced by volume loading. In 1975, Richard attended his first AATS meeting with his father, a thoracic surgeon from Milwaukee. He was introduced to the AATS president at the time, Dr Wilfred Bigelow, who arranged for Richard to begin his thoracic surgical training at the University of Toronto the next year. Richard has been appointed at the University of Toronto ever since. Richard was a young faculty member in Toronto when I was doing my thoracic surgical training. After I joined the faculty, he was extraordinarily helpful to me in establishing my own independent laboratory program. He has contributed to the success of many others as well.

His major research interests have been myocardial protection and stem cell therapy. Basic investigations and then clinical trials determined that antegrade and retrograde tepid blood cardioplegia provided improved protection. Stem cells regenerate the heart after an infarct, and their transplantation improves the recovery of heart function after coronary artery bypass grafting. Richard's close colleague and friend of more than 30 years, AATS Past President Tirone David states, "Richard's curriculum vitae summarizes the "evolution' of his academic life very well. He started by examining the entire heart in the 1970s, then got into its cellular struc-

\footnotetext{
From the Division of Cardiothoracic Surgery, Washington University School of Medicine, St Louis, Mo.

Address for reprints: Alec Patterson, MD, Evarts A. Graham Professor of Surgery, Chief, Division of Cardiothoracic Surgery, Washington University School of Medicine, 660 South Euclid Ave, Campus Box 8234, St Louis, MO 63110 (E-mail: pattersona@wustl.edu).

J Thorac Cardiovasc Surg 2010;140:1-2 $0022-5223 / \$ 36.00$

Copyright (c) 2010 Published by Elsevier Inc. on behalf of The American Association for Thoracic Surgery

doi:10.1016/j.jtcvs.2010.04.006
}

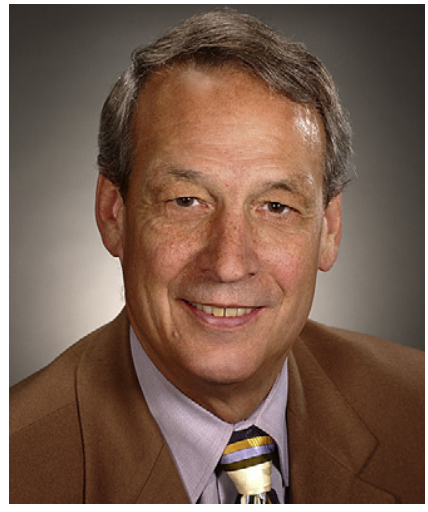

ture and metabolism in the 1980s, and moved to molecules and gene regulation and finally to regeneration. At every stage of this academic odyssey, he was always at the forefront, a visionary and tireless worker." Richard elucidated the molecule events of myocardial ischemiareperfusion injury. He embraced molecular biology and brought it into the clinical practice of cardiac surgery.

The accomplishment of which Richard is most proud, however, is the mentoring of a cadre of more than 20 cardiac surgical scientists. For more than 30 years, he has directed a vibrant laboratory enterprise that has attracted dozens of students working as research assistants. This teaching environment came to be known as "Camp Weisel." Many of these individuals have gone on to their own successful academic careers in cardiothoracic surgery, with a number of them currently University of Toronto faculty members. More than 25 years ago, Dr Weisel was instrumental in developing the Surgical Scientist Program at the University of Toronto. This innovative program has allowed interested surgical residents an opportunity to obtain outstanding research training and achieve a master's or doctoral degree before completion of senior residency training.

Dr Weisel's research program combines clinical and basic scientists working together to provide superior scientific achievement while retaining clinical relevance. The combination of basic science and clinical trainees working together has enhanced the efforts of both groups. This integrated, multidisciplinary enterprise is a model for academic cardiothoracic surgeons worldwide. These laboratory investigations and related clinical studies have been continuously funded by the Heart Foundation, the Medical Research Council of Canada, and the Canadian Institutes for Health Research since 1978. Dr Weisel's research group has produced more than 400 peer-reviewed publications.

Dr Weisel currently serves as director of the Toronto General Hospital Research Foundation and Professor of Cardiac 
Surgery at the University of Toronto. An honorary member of the AATS, he is the recipient of an impressive list of honors for his outstanding work: Research Achievement Award, Canadian Cardiovascular Society; Charles Tator Surgeon-Scientist Mentoring Award, University of Toronto; Mentor Award, Council on Cardiovascular Surgery, American Heart Association; Earl Bakkin Scientific Achievement Award, Society of Thoracic Surgeons; Wilfred Bigelow Lectureship, Canadian Society of Cardiac Surgeons; Distinguished Achievement Award, American Heart
Association; Honored Guest Lecturer, American Association for Thoracic Surgery; and William W. L. Glenn Lecturer, American Heart Association.

Richard Weisel has devoted his career to the translation of the latest scientific developments into new clinical approaches to cardiothoracic disease. His constant commitment to outstanding science and his infectious good humor have stimulated 2 generations of young cardiac surgeons to follow in his footsteps, perhaps the most important achievement of an illustrious academic career. 